\title{
A Comparative Study of the Commercially Available Fungicides to Control Sheath Blight of Rice in Lahore
}

Ahmad Ali Shahid ${ }^{1}$, Muhammad Shahbaz ${ }^{2}$ and Muhammad Ali" ${ }^{*}$

${ }^{1}$ Institute of Agricultural Sciences, University of the Punjab, Lahore, Pakistan

${ }^{2}$ Department of Pest warning and Quality control of pesticides, Govt. of Punjab, Lahore, Pakistan

\begin{abstract}
A comparative study of commercially available fungicides (Cordate, Precurecombi, Curon, Bendict, Nativo, Valedamycin and Tilt) was made to find out the best fungicide against sheath blight fungi (Rhizoctoniasolani). Experimental field was divided into nine treatment units (T1, T2, T3, T4, T5, T6, T7, T8 and T9) and each unit was treated with each fungicide and data was collected on the basis of different agronomic traits such as number of tillers per hill, number of grains per spike, 1000 grain weight, disease incidence and yield of crop. As a result fungicides Nativo and Tilt were proved to be best control for sheath blight of rice.
\end{abstract}

Keywords: Sheat blight of rice; Rhizoctonia solani; Rice; Chemical control

\section{Introduction}

Rice (Oryza sativa L.), a member of the family Graminae is widely grown in tropical and subtropical regions [1]. Approximately $90 \%$ of the world's rice is grown in the Asian continent and constitutes a staple food for 2.7 billion people worldwide [2]. In Pakistan it is the second most important staple food after wheat (Triticum aestivum) and is also one of the main export items of the country. During 2005-2006 the crop was grown over an area of 2621.4 thousands hectares with 5547.2 thousands tones production [3]. Pakistan is on the fourth number among rice exporting countries. The Punjab province produces $69 \%$ of the total rice production of the country. Area under cultivation of rice is getting decreased due to urbanization and now it is requirement of time to improve cultivation practices along with plant protection practices.

Sheath blight, caused by Rhizoctonia solani Kühn, is one of the most destructive rice (Oryza sativa L.) diseases worldwide [4]. Asexual stage of $R$. solani belonging to Fungi imperfecti, hyphomycetes, Agonomycetales was called $R$. solani while sexual stage belonging to Basidiomycota, hymenomycetes, homobasidiomycetida, Tulasnellale was called Thanatephorus cucumeris. Sclerotium stage belongs to Rhizoctonia, Tulasnellaceae, and ThanatepHorus. R. solani is one type of filamentous fungi. It is pathogenic to economically important crops such as rice, wheat, maize, cotton, potato, bean, vegetables and grasses [5-10]. This fungus is responsible for the root rot, stem-foot rot as well as seedling blight $[11,12]$.

In occurrence fields, rice yield usually reduced by $10-30 \%$, even up to $50 \%$, owing to this disease [13]. Sheath blight often prevails in rice field with high plant density and high application rate of nitrogen fertilizer. Besides, with the extension of semidwarf, high-yielding, and multitiller cultivars, this disease has been aggravated in recent years, and becomes the most important disease in rice regions $[14,15]$.

Following field trials were made to evaluate the commercially available best fungicide with potential to control sheath blight of rice and later on transfer this information to farmer level in order to get maximum yield of the crop.

\section{Materials and Methods}

\section{Identification of infected field}

A field of rice variety KSK-133 was identified as infected with sheath blight at Tatlly Malian, Lahore. Field was identified on the basis of visual symptoms on the standing crop plants. Photography was done in order to keep the records of visual symptoms. Samples of infected plants were also collected for the microscopic authentication of pathogenic fungal organism (Plate 1).

\section{Pathogen verification}

Infected samples were brought to the laboratory of Institute of Agricultural Sciences, University of the Punjab, Lahore. These samples were surface sterilized and inoculated on the Malt Extract Agar (MEA) and Potato Dextrose Agar (PDA) medium containing petriplates. Plates were then incubated at $27^{\circ} \mathrm{C}$ for four days. After the germination of mycelia growth the slides were prepared and organism was identified by means of several morphological features as well as identification manuals and keys.

\section{Experimental design}

Field trial was conducted during the rice crop of year 2012. Experiment was laid out in randomized complete block design with 4 blocks and 9 treatments. Area under experiment was 2 acre.

\section{Pretreatment data}

Before treatment of fungicide in the field the disease incidence in the field was scattered and was evaluated by means of following formula (Table 1):

*Corresponding author: Muhammad Ali, Institute of Agricultural Sciences University of the Punjab, Lahore, India, Tel: +92 42 99231105; E-mail: Muhammadali.mycologist@gmail.com

Received: August 26, 2014; Accepted October 30, 2014; Published October 31 2014

Citation: Shahid AA, Shahbaz M, Ali M (2014) A Comparative Study of the Commercially Available Fungicides to Control Sheath Blight of Rice in Lahore. J Plant Pathol Microb 5: 240. doi:10.4172/2157-7471.1000240

Copyright: @ 2014 Shahid AA, et al. This is an open-access article distributed under the terms of the Creative Commons Attribution License, which permits unrestricted use, distribution, and reproduction in any medium, provided the original author and source are credited. 
Citation: Shahid AA, Shahbaz M, Ali M (2014) A Comparative Study of the Commercially Available Fungicides to Control Sheath Blight of Rice in Lahore. J Plant Pathol Microb 5: 240. doi:10.4172/2157-7471.1000240
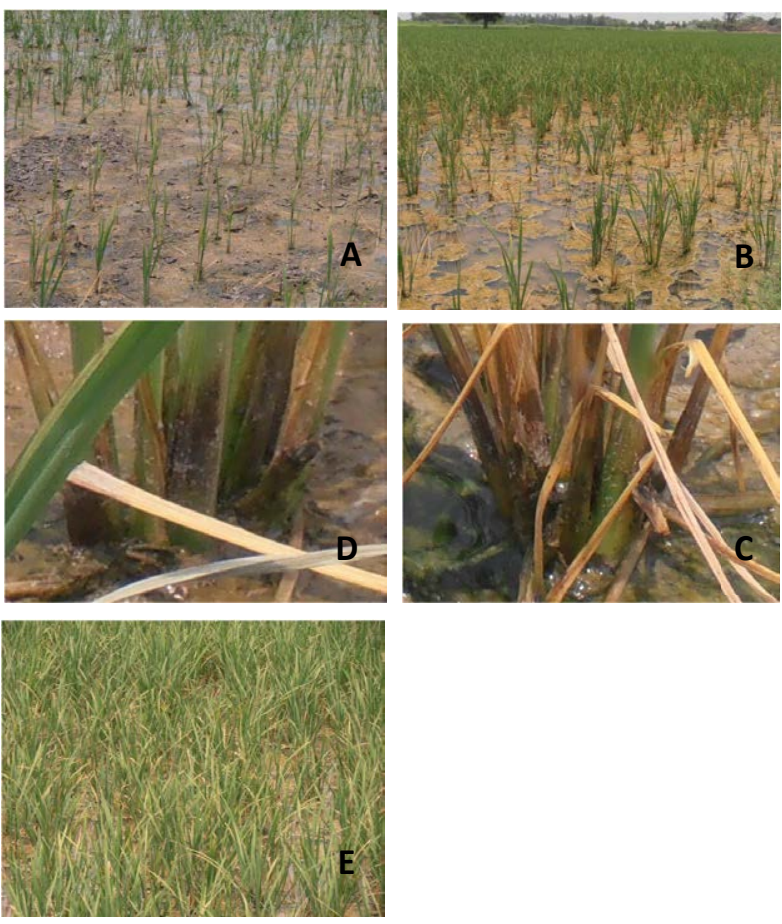

A\&B: Rice field infected with sheath blight. C\&D: Infected root zone of the diseased plants. E: Best recovered unit after treatment

Plate 1: Pictorial presentation of the experiment

\begin{tabular}{|c|c|c|c|c|c|c|c|c|c|c|}
\hline S. No & Observations & T1 & T2 & T3 & T4 & T5 & T6 & T7 & T8 & T9 \\
\hline 1 & $\begin{array}{c}\text { Av. No of tillers per } \\
\text { hill }\end{array}$ & 4 & 5 & 7 & 9 & 12 & 8 & 11 & 9 & 4 \\
\hline 2 & Av. No of grains & 85 & 95 & 90 & 110 & 126 & 100 & 117 & 100 & 75 \\
\hline 3 & $\begin{array}{c}\text { 1000 grain weight } \\
\text { (gm) }\end{array}$ & 22 & 26 & 28 & 33 & 31 & 25 & 29 & 23 & 22 \\
\hline 4 & $\begin{array}{c}\text { Disease incidence } \\
\text { (\%) }\end{array}$ & 65 & 58 & 45 & 40 & 38 & 65 & 62 & 58 & 55 \\
\hline
\end{tabular}

Table 1: Pretreatment data in each of the selected blocks.

Disease incidence $=\frac{\text { Number of infected plants }}{\text { Total Number of plants visited }} \times 100$

Along with the disease incidence the following crop parameters were also observed and recorded for each plot.

a. Average number of tillers per hill

b. Average number of grains per spike

c. 1000 grains weight

d. Disease incidence

\section{Fungicide treatment}

The fungicidal treatment was given to each infected plot in order to evaluate the comparative potential of each fungicide to control the sheath blight (Table 2).

\section{Results and Discussion}

\section{Pathogen identification}

Pathogenic fungi was isolated at the Institute of Agricultural
Sciences, University of the Punjab, Lahore. Pathogen was identified as Rhizoctoniasolani.

\section{Disease incidence}

Disease incidence before treatment of fungicide in the field was infested highly with disease. Disease incidence after treatment of fungicides, the observation collected about disease in the field in response to fungicide application was as follows:

The best control against sheath blight was found in T5 and T7, T4 (Figure 1) stood at second number while T3, T6 and T8 results were almost same in controlling the disease and $\mathrm{T} 2$ and $\mathrm{T} 1$ gave less control along with no control of disease in the experimental unit of T9.

\section{Number of tillers per hill}

The average number of tillers were calculated after treatment of fungicides in the field were as follows: Maximum number of tillers were found in T5 along with T4 and T7 while other treatment gave average number of tillers, minimum number of tillers were found in T9.

\section{Number of grains per spike}

Maximum average number of grains per spike were observed in T5, T4, and T7 respectively. T3, T6 and T2 gave medium number of grains per spike, minimum number of grains were found in $\mathrm{T} 9$.

\section{0 grain weight in grams}

1000 grains were collected from the spikes of each experimental units and their weight was recorded in grams and it is given in table (Table 2 and Figure 1).

\section{Yield of crop}

Yield of rice crop was recorded and explained in table. The best results were found in T5 (Table 3).

\begin{tabular}{|c|c|c|}
\hline Treatments & Name of fungicide & Dose per Acre \\
\hline T1 & Cordate & $75 \mathrm{gm}$ \\
\hline T2 & Precurecombi & $62.5 \mathrm{gm}$ \\
\hline T3 & Curon & $50 \mathrm{ml}$ \\
\hline T4 & Bandict & $62.5 \mathrm{ml}$ \\
\hline T5 & Nativo & $15 \mathrm{gm}$ \\
\hline T6 & Valedamycin & $25 \mathrm{ml}$ \\
\hline T7 & Tilt & $50 \mathrm{ml}$ \\
\hline T8 & Curon (Flooding) & $100 \mathrm{ml}$ \\
\hline T9 & Control & \\
\hline
\end{tabular}

Table 2: Treatment details of each infected plot.

Rice crop data in the selected field units after treatment

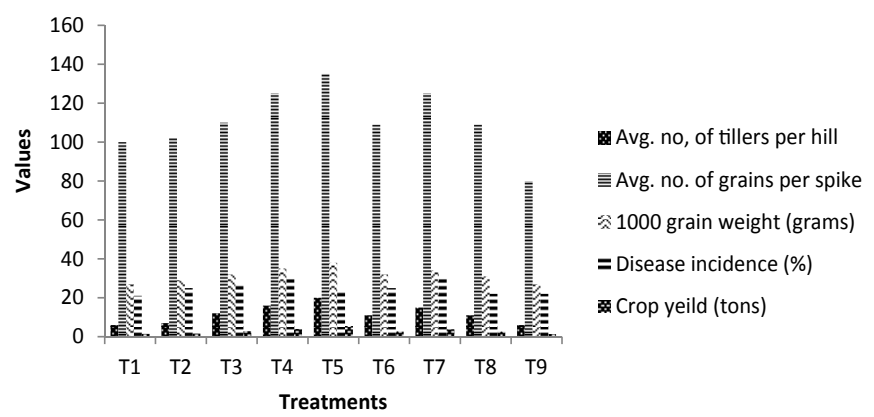

Figure 1: Rice crop data in the selected field units after treatment. 
Citation: Shahid AA, Shahbaz M, Ali M (2014) A Comparative Study of the Commercially Available Fungicides to Control Sheath Blight of Rice in Lahore. J Plant Pathol Microb 5: 240. doi:10.4172/2157-7471.1000240

\begin{tabular}{|c|c|c|c|c|c|c|c|c|c|c|}
\hline S.no & Observations & T1 & T2 & T3 & T4 & T5 & T6 & T7 & T8 & T9 \\
\hline 1 & Av. No of tillers per hill & 6 & 7 & 12 & 16 & 20 & 11 & 15 & 11 & 6 \\
\hline 2 & Av. No of grains & 100 & 102 & 110 & 125 & 135 & 109 & 125 & 109 & 80 \\
\hline 3 & 1000 grain weight (gm) & 27 & 29 & 32 & 35 & 38 & 32 & 34 & 31 & 27 \\
\hline 4 & Disease incidence (\%) & 21 & 25 & 27 & 30 & 23 & 25 & 31 & 22 & 22 \\
\hline 5 & Crop Yield (Kg) & 1439 & 1594 & 2838 & 3930 & 5462 & 2577 & 3793 & 2503 & 1360 \\
\hline
\end{tabular}

Table 3: Rice crop data in the selected field units after treatment.

\section{Conclusion}

Sheath blight of rice is one of the most devastating diseases of rice. In Punjab, Pakistan the losses due to this infection varies from 30 to $50 \%$. Nativo was found to be the best fungicide used against sheath blight of rice. Benomyl was reported to be mostly used for this disease but Nativo is another new addition to the group of fungicides used to control sheath blight of rice. In the recent research work Nativo, Bandict and Tilt have shown better result in the field against this disease. These pesticides have improved the agronomic features of the rice crop such as Average number of tillers per hill, Average number of grains, weight of 1000 grains in grams, disease incidence and crop yield. These pesticides was also recommended to local farmers to be applied for sheath blight of rice and the results were quite satisfactory. The economics of the recommended pesticides was also evaluated and found that Nativo require only $350 \mathrm{ml} / \mathrm{ha}$, Bandict $520 \mathrm{ml} / \mathrm{ha}$ and Tilt $550 \mathrm{ml} / \mathrm{ha}$. Whereas the required concentration of rest of the pesticides lies in the range of $1000 \mathrm{ml} / \mathrm{ha}$. The cost of Nativo, Bandict and tilt is $350,300,430$ respectively which is very economical for the local farmer. Cordate is an old fungicide which is used in rice canopy and causes resistance in pathogen. Hence it is time to replace the old fungicides with new and alternate fungicides especially in a monocropping system like rice.

\section{References}

1. Achmadi P, Verma E, Escopalao, Naomi G, Tangonan, et al. (2001) Characterization of a New Subgroup of Rhizoctonia solani Anastomosis Group 1 (AG-1-ID), Causal Agent of a Necrotic Leaf Spot on Coffee. Ecol Popul Biol 91: 1054-1061.

2. Anonymous (2006) Agricultural Statistics of Pakistan. Government of Pakistan Ministry of food, agricultural and livestock (Economic Wing), Islamabad. pp. 13-17.

3. Ezuka A, Kaku H (2000) A historical review of bacterial blight of rice. National Institute of Agro-biological Research Bulletin, Japan. pp. 207.
4. He Z, Li HX, Tang HR (2010) Effect of Arbuscular Mycorrhizal Fungi on Endogenous in Cucumber after Rhizoctonia solani Inoculation. Chinese Agr Sci Bull 26: 187-190.

5. Hu C, Wei YW, Huang SL, Shi G, Li YR (2010). Identification and Characterization of Fungal Strains Involved in Rice Sheath Blight Complex in Guangxi Province. Acta Agr Boreali-occidentalis Sinica 19: 45-51.

6. Huang JH, Zeng R, Luo SM (2004) Studies on disease resistance of maize toward sheath blight induced by arbuscular mycorrhizal fungi. Chin J Eco-Agr 14: 167-169.

7. Liao HNL, Xiao S, Wang HS (1997) Analysis of developing annals and evolving causation of rice sheath blight. Guangxi Plant Prot 1997: 35-38.

8. Li F, Cheng LR, Xu MR, Zhou Z, Zhang Y, et al. (2009) QTL mining for sheath blight resistance using the backcross selected introgression lines for grain quality in rice. Acta Agron Sin 35: 1729-1737.

9. Salim M, Akram M, Akhtar ME, Ashraf M (2003) Rice, A production Hand Book Pakistan Agricultural Research Council, Islamabad. pp. 70.

10. Shi RC, Shang HS, Zhang JZ (2007). Nucleus number of Rhizoctonia mycelium cells from turf-grasses in China. Mycosystema, 26: 221-225.

11. Slaton NA, Cartwright RD, Meng J, Gbur EE, Norman RJ (2003) Sheath bligh severity and rice yield as affected by nitrogen fertilizer rate, application method and fungicide. Agron J, 95: 1489-1496.

12. Tan ZJ, Hao SZ (2007) Potato Rhizoctonia canker as well as prevention and cure. China Potato 21(2): 108-109.

13. Willocquet LL, Fernandez, Savary S (2000) Effect of various crop establishment methods practised by Asian farmers on epidemics of rice sheath blight caused by Rhizoctoniasolani. Plant Pathol 49: 346-354.

14. Xiao Y, Li SC, Chu MG, Zhou P, Guan P (2008) Cloning, Expression and Characterization of $\mathrm{G}$ Protein $\beta$-subunit Gene in Rhizoctonia solani from Rice. Chinese J Rice Sci 22: 541-544.

15. Yang JH, Guo QY, Ji L (2005) Study on anastomosis groups Rhizoctonia solan isolated from six Leguminaceous crops in Xinjiang. Xinjiang Agr Sci 42: 382385 